\title{
実験的糖尿病における凝血因子と 血管障害に関する研究
}

\author{
ことに各種食餌の影響について
}

\author{
䒠澤 公徳 \\ 日本医科大学第 1 内科学教室 (主任: 木村栄一教授)
}

\section{楮䨔}

榙尿病が動脈硬化性疾患を合併しやすいことはすで に周知の事実であるが，なせ動脈硬化症がおこりやす いかについてはまだ明確な説明はなされていない，一 方，動脈硬化の原因の 1 つとして hypercoagulability があげられている，その意味からいうと，糖尿病患者 における凝血因子の消長をしらべることが必要であ る.

糖尿病における hypercoagulabilityに関する最初 の報告は, Valdorf-Hansen" によれば Giannico and Morrazza ${ }^{21}$ とされる.彼らは榶氺病患者において第 1 因子(フィブリ)ーゲン，Fbg) の増量していること， さらに凝血時間, 出血時間などの global test time の短縮していることを観察し、これより糖尿病がいわ ゆる “hypercoagulability”の状態にあることを指摘 した.

その後, 凝血学のいちじしい進歩にともない，糖 症病患者に関するいろいろの研究がなされるよ5に なったが，詳細にしらべた報告は意外に少なく， Egeberg $^{31}$ ，国島“，佐竹 $5^{51}$ ，Valdorf-Hansen"によ るものがある程度にすぎない，実験的糖尿病動物の凝 血能についても，Kalant ら`)，氏家”の報告が散見さ れるだけである.

これらの文献を参照すると，全体としては糖尿病に おける凝血能の六進状態が観察されているが，個々の 凝血因子についての検索成績は必ずしも一致していな い.

凝血能と脂質代謝の間に密接な関係のあることも，

ASHIZAWA, KIMINORI : Studies on the changes in clotting factors and vascular lesion in experimental alloxan diabetes of rabbits, with special reference to the effects of various diets.
多くの研究者により報告されているところであり，糖 尿病における脂梊代謝の異常は糖尿病の特徽の 1 つと されている，しかし，栯尿病における疑血能と脂啠代 謝の関係につき詳細な研究を行った報告もやはり少な 以.

一方, 高脂肪食投与による高コレステロール血症お 上び高脂血症は，高蛋白食により轻隇することが実験 的に観察されており ${ }^{8 \sim 10)}$ ，実験的粥状動脈硬化の発生 が高蛋白食により抑制されるとの報告もある ${ }^{13,14)}$. 反 対に，低蛋白食は高コレステロール血症，高脂血症を 助長し, 動脈硬化症発生を促進させるといら成績も報 告されている25,10).

このような高蛋白食の効果は，糖尿病における高コ レステロール血症, 高脂血症に対しても当然みられる ところと考えられるが,この点を追求した論文もほと んどない。

これら多くの問題を解決するために，著者は実験的 糖尿病ウサギおよび正常ウサギにおいて，高蛋白食を 含む各種食䬺が，脂啠ならびに凝血能にいかなる影瑤 を及ぼすかについての検索を行った。

\section{実呀方法}

\section{（1）実験対象および食餉}

体重 $2 \mathrm{~kg}$ 前後の雄ウサギ 48 羽を対象とし, 表 1 のごとく 31 羽にはアロキサンを静注して糖尿病を作 成 (DM ウサギ)，17 羽はコントロール（非 DM ウサギ）としたおのおのを 4 群にわけ，それぞれ高 脂肪食 ( $\mathrm{F}$ 群), ラノリン食 ( $\mathrm{L}$ 群), 高蛋白食 ( $\mathrm{P}$ 群)，普通食（N 群）をもって飼育した. それぞれの 食䬣の組成は表 1 に示すごとくである．普通食 (N群) としては Oriental 社製の一般ウサギ飼育飼料を用い， 他は Oriental 社に特別に注文作成させた固形飼料を 用いた. 1 日の摇取カロリーは各群とも250カロリー 
表 1 各食期群における食郋組成

\begin{tabular}{|c|c|c|c|c|c|c|c|c|}
\hline & \multirow{2}{*}{$\begin{array}{l}\frac{D}{M} \\
\stackrel{7}{*}\end{array}$} & \multirow{2}{*}{$\begin{array}{l}\text { 韭ウ } \\
D+\# \\
M \neq\end{array}$} & \multicolumn{6}{|c|}{ 食慨組成（而比写） } \\
\hline & & & $\begin{array}{l}\text { 念水 } \\
\text { 医㷛 }\end{array}$ & $\begin{array}{l}\text { 蛋白 } \\
\text { 覔 }\end{array}$ & 脂肪 & 䋐維 & 质分 & 水分 \\
\hline $\begin{array}{l}\text { 高脂肪食 } \\
(\text { F }) \text { 群 }\end{array}$ & 11 羽 & 4 羽 & 43.5 & 17.7 & 14.2 & 10.6 & 7.0 & 7.0 \\
\hline (゙リ)群 & 5 & 4 & 43.3 & 17.7 & $\begin{array}{l}14.2 \\
\text { 念ラ人 } \\
\text { リ. } \\
3.3 \%\end{array}$ & )$^{5.5}$ & 7.0 & 5.1 \\
\hline $\begin{array}{l}\text { 高蛋白食 } \\
\text { (P)群 }\end{array}$ & 10 & 5 & 34.5 & 36.0 & 3.5 & 10.0 & 9.0 & 7.0 \\
\hline $\begin{array}{l}\text { 普通食 } \\
(\mathrm{N}) \text { 群 }\end{array}$ & 5 & 4 & 51.0 & 20.5 & 3.0 & 11.5 & 8.0 & 6.0 \\
\hline 計 & 31 & 17 & & & & & & \\
\hline
\end{tabular}

とした。飲水量は自由に与えた。

（2）糖尿病作成法

まず普通食で約 1 力月飼育, さらに表1のそれぞれ の食䭒で 2 3 週間飼育したのち, 生理食塩水に溶解 したアロキサン $150 \mathrm{mg} / \mathrm{kg}$ を耳静脈に注射してアロ キサン榶疗病を作成した，低血榶症状を示したものに は $40 \%$ ブドウ糖 $20 \mathrm{~m} l$ を静注して低血精による死亡 を防いだ.アロキサン処置後約 1 週間経過したとき, 12 15 時間飢諓後の血糖値が $200 \mathrm{mg} / \mathrm{d} l$ 以上を示す ウサギを，DM ウサギとして使用した。

(3) 検查項目および方法

1) 凝血学的検查

限られた血液量で検查を行なわなければならぬ関係 上，下記の検査項目および方法を選んだ. 以下，(） 内に示したごとき略語を用いることにする.

i ）Quick 1 段法によるプロトロンビン活性值 (Quick 值) : Quick 原法 ${ }^{\text {'? }}$

ii）プロトロンビン活性值 (Koller 值) : Koller ら ${ }^{18)}$ の 1 段法を一部改変した佐竹の方法 ${ }^{19}$

iii) 第V因子活性值 (V): Wolf 変法 ${ }^{20}$

iv) 第VII因子複合体活性值 (VI) : Koller 5の方法 を改変した佐竹の変法 ${ }^{21}$. 本法は第VI因子と第 X因子 の活性値を複合体として反映する。

v) トロンボプラスチン形成試験 (TGT) : BiggsMacfarlane 法 ${ }^{22}$. 吸着血諆の TGT ( $p$-TGT) 施 V因子，第明因子の活性值を，血清のそれ( $s-T G T)$ 注第X因子，第X因子の活性值を複合体として反映す る.

vi）血㓋フィブリノーゲン（Fbg）：比色法を用い るチロジン法 ${ }^{23)}$.

vii) Thrombelastogram (TEG): Hellige 社製 Thrombelastograph を使用し, 全血につき $(r+k)$ と ma を計測した。

上記各凝血因子のうち, Quick 值, Koller 值, V、VII, $s$-TGT, $p$-TGT については, 测定の都度 健康人 2 3 人よりえた值をスタンダードとし，そ の值を $100 \%$ としてそれぞれの凝血因子の值を求め た。

2) 血液生化学的検查

i ) 血榶: Autoanalyser 法

ii）総コレステロール (TC) : Zak·Henly 法

iii) トリグリセリド (TG) : Van Handel \& Zilversmit 法

iv）燐脂犋 (PL) : Fiske \& Subbarow 法

v) GOT および GPT : Reitman-Frankel 法

以上の凝血学的・生化学的唡索のための血液は, 12 〜15 時間飢餓としたのち，心嘰穿刺により採取した。 2 週間ごとに測定するため，探血による影警を考虑し て，1回の探血量を $8 \sim 10 \mathrm{ml}$ にとどめた.

3）凝血因子および脂䋢測定時期

実験的に糖尿病を作成するのに用いられるアロキサ
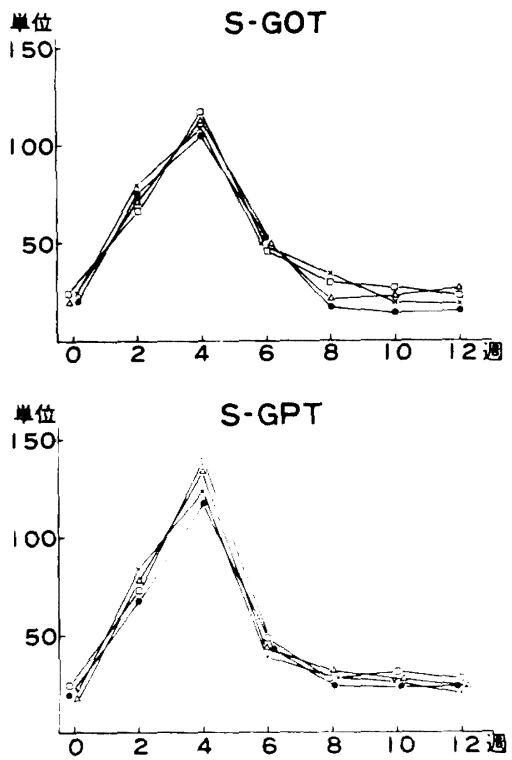

四1 アロキサンの血清トランスアミラーゼ におよほす影留

$\triangle \longrightarrow$ 高脂肪食 (F) 群，ローロ ラノリン

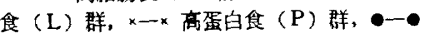
普通食 (N) 群 
$-18-(318)$

ンは肝臈を障害することが知られており，肝障害は血 清生化学諸值,凝固系に少なからざる影整を及隹す20). アロキサン投与後の GOT, GPT につきしらべたとこ ろ図1のごとき成績がえられ，GOT，GPT ともにア ロキサン静注後 4 週目に最高値に達し，8 週目に正常
值に復し，以後各食解群とも正常做を保つのがみられ た.よってアロキサン静注後 8 週以上たってからの値 を，検郡の対象とするのが妥当と考えられるので，凝 血因子, 脂啠ともに 8 週, 10 週, 12 週の 3 回に測定 を行った。

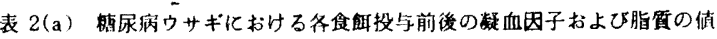

\begin{tabular}{|c|c|c|c|c|c|}
\hline & & F 群 & L 群 & P 群 & N 群 \\
\hline Quick (क) & $\begin{array}{l}\text { 前 } \\
\text { 後 }\end{array}$ & $\begin{array}{l}299.2 \pm 28.9 \\
455.8 \pm 41.5\end{array}$ & $\begin{array}{l}304.5 \pm 19.3 \\
306.6 \pm 43.5\end{array}$ & $\begin{array}{l}303.3 \pm 27.6 \\
302.7 \pm 37.1\end{array}$ & $\begin{array}{l}300.9 \pm 21.3 \\
286.0 \pm 26.5\end{array}$ \\
\hline Koller (㝝) & $\begin{array}{l}\text { 前 } \\
\text { 後 }\end{array}$ & $\begin{array}{l}216.2 \pm 20.9 \\
334.5 \pm 31.8\end{array}$ & $\begin{array}{l}209.3 \pm 21.4 \\
292.0 \pm 29.2\end{array}$ & $\begin{array}{l}206.8 \pm 18.8 \\
290.7 \pm 37.9\end{array}$ & $\begin{array}{l}200.9 \pm 17.8 \\
251.2 \pm 11.3\end{array}$ \\
\hline $\mathrm{V}(\%)$ & $\begin{array}{l}\text { 前 } \\
\text { 後 }\end{array}$ & $\begin{array}{c}884.1 \pm 35.1 \\
1.666 .3 \pm 249.2\end{array}$ & $\begin{array}{c}880.9 \pm 33.8 \\
1.750 .0 \pm 108.4\end{array}$ & $\begin{array}{l}886.0 \pm 29.8 \\
951.3 \pm 89.4\end{array}$ & $\begin{array}{r}883.3 \pm 31.6 \\
1,192.2 \pm 41.9\end{array}$ \\
\hline VII (\%) & $\begin{array}{l}\text { 前 } \\
\text { 後 }\end{array}$ & $\begin{array}{l}158.3 \pm 13.8 \\
308.5 \pm 17.7\end{array}$ & $\begin{array}{l}160.4 \pm 10.5 \\
373.4 \pm 7.4\end{array}$ & $\begin{array}{l}163.7 \pm 13.2 \\
152.8 \pm 10.1\end{array}$ & $\begin{array}{l}156.5 \pm 12.3 \\
192.2 \pm 19.4\end{array}$ \\
\hline$s-$ TGT (\%) & 前 & $\begin{array}{l}37.6 \pm 1.3 \\
48.2 \pm 2.9\end{array}$ & $\begin{array}{l}37.2 \pm 1.8 \\
38.8 \pm 2.6\end{array}$ & $\begin{array}{l}37.1 \pm 0.2 \\
37.9 \pm 3.2\end{array}$ & $\begin{array}{l}36.9 \pm 2.1 \\
37.0 \pm 1.6\end{array}$ \\
\hline$p$-TGT (96) & $\begin{array}{l}\text { 前 } \\
\text { 後 }\end{array}$ & $\begin{array}{r}81.5 \pm 3.1 \\
111.0 \pm 4.5\end{array}$ & $\begin{array}{r}84.3 \pm 5.6 \\
158.4 \pm 4.9\end{array}$ & $\begin{array}{l}82.6 \pm 1.9 \\
90.9 \pm 6.5\end{array}$ & $\begin{array}{l}80.3 \pm 3.4 \\
90.8 \pm 4.8\end{array}$ \\
\hline $\mathrm{Fbg}(\mathrm{mg} / \mathrm{d} l)$ & $\begin{array}{l}\text { 前 } \\
\text { 後 }\end{array}$ & $\begin{array}{l}509.3 \pm 23.9 \\
700.9 \pm 39.2\end{array}$ & $\begin{array}{l}507.2 \pm 25.6 \\
627.0 \pm 36.3\end{array}$ & $\begin{array}{l}504.9 \pm 20.8 \\
479.1 \pm 25.9\end{array}$ & $\begin{array}{l}506.0 \pm 19.3 \\
471.8 \pm 28.4\end{array}$ \\
\hline $\operatorname{TEG}(r+k)(\mathrm{mm})$ & 前 & $\begin{array}{l}28.2 \pm 1.2 \\
23.5 \pm 1.5\end{array}$ & $\begin{array}{l}28.1 \pm 0.9 \\
21.9 \pm 1.3\end{array}$ & $\begin{array}{l}28.0 \pm 1.1 \\
29.9 \pm 1.3\end{array}$ & $\begin{array}{l}28.0 \pm 0.8 \\
27.7 \pm 1.0\end{array}$ \\
\hline TEG ma $(\mathrm{mm})$ & $\begin{array}{l}\text { 前 } \\
\text { 後 }\end{array}$ & $\begin{array}{l}64.0 \pm 14 \\
71.6 \pm 1.5\end{array}$ & $\begin{array}{l}64.2 \pm 1.3 \\
77.5 \pm 1.3\end{array}$ & $\begin{array}{l}63.9 \pm 1.8 \\
59.9 \pm 3.4\end{array}$ & $\begin{array}{l}64.7 \pm 1.5 \\
65.2 \pm 2.1\end{array}$ \\
\hline $\mathrm{TC}(\mathrm{mg} / \mathrm{d} l)$ & 前 & $\begin{array}{r}81.8 \pm 13.6 \\
441.7 \pm 39.5\end{array}$ & $\begin{array}{r}86.5 \pm 14.3 \\
524.2 \pm 24.6\end{array}$ & $\begin{array}{r}80.7 \pm 11.9 \\
103.5 \pm 15.2\end{array}$ & $\begin{array}{r}85.4 \pm 14.1 \\
207.8 \pm 27.7\end{array}$ \\
\hline $\mathrm{TG}(\mathrm{mg} / \mathrm{d} l)$ & $\begin{array}{l}\text { 前 } \\
\text { 後 }\end{array}$ & $\begin{array}{r}78.8 \pm 20.1 \\
390.0 \pm 35.2\end{array}$ & $\begin{array}{r}83.1 \pm 10.6 \\
584.6 \pm 18.9\end{array}$ & $\begin{array}{c}80.4 \pm 12.2 \\
150.8 \pm 8.3\end{array}$ & $\begin{array}{r}82.6 \pm 14.8 \\
234.0 \pm 27.5\end{array}$ \\
\hline $\mathrm{PL}(\mathrm{mg} / \mathrm{d} l)$ & $\begin{array}{l}\text { 前 } \\
\text { 後 }\end{array}$ & $\begin{array}{c}85.7 \pm 7.3 \\
263.5 \pm 12.2\end{array}$ & $\begin{array}{r}86.6 \pm 10.3 \\
331.0 \pm 21.0\end{array}$ & $\begin{array}{c}87.0 \pm 9.2 \\
137.9 \pm 16.4\end{array}$ & $\begin{array}{c}86.3 \pm 7.6 \\
178.4 \pm 10.7\end{array}$ \\
\hline
\end{tabular}

mean \pm S. D.

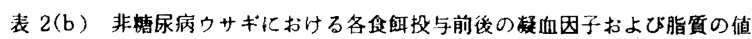

\begin{tabular}{|c|c|c|c|c|c|}
\hline & & F 群 & L群 & P群 & N群 \\
\hline Quick (96) & $\begin{array}{l}\text { 前 } \\
\text { 後 }\end{array}$ & $\begin{array}{l}311.0 \pm 28.5 \\
364.0 \pm 47.2\end{array}$ & $\begin{array}{l}325.6 \pm 24.8 \\
273.5 \pm 19.2\end{array}$ & $\begin{array}{l}306.2 \pm 23.1 \\
331.4 \pm 21.9\end{array}$ & $\begin{array}{l}302.0 \pm 38.7 \\
310.0 \pm 51.7\end{array}$ \\
\hline Koller (क) & $\begin{array}{l}\text { 前 } \\
\text { 後 }\end{array}$ & $\begin{array}{l}219.9 \pm 18.2 \\
265.0 \pm 23.5\end{array}$ & $\begin{array}{l}215.3 \pm 16.8 \\
300.0 \pm 40.8\end{array}$ & $\begin{array}{l}213.7 \pm 11.6 \\
222.2 \pm 19.8\end{array}$ & $\begin{array}{l}204.8 \pm 22.6 \\
250.0 \pm 14.5\end{array}$ \\
\hline $\mathrm{V}(\%)$ & $\begin{array}{l}\text { 前 } \\
\text { 後 }\end{array}$ & $\begin{array}{r}892.6 \pm 30.4 \\
1,100.0 \pm 29.2\end{array}$ & $\begin{array}{r}882.3 \pm 29.6 \\
1.381 .0 \pm 65.5\end{array}$ & $\begin{array}{l}884.2 \pm 23.6 \\
990.2 \pm 66.0\end{array}$ & $\begin{array}{l}890.1 \pm 31.2 \\
866.0 \pm 68.7\end{array}$ \\
\hline VII (क) & $\begin{array}{l}\text { 前 } \\
\text { 後 }\end{array}$ & $\begin{array}{l}157.9 \pm 13.6 \\
221.5 \pm 16.3\end{array}$ & $\begin{array}{l}161.8 \pm 12.4 \\
250.8 \pm 7.4\end{array}$ & $\begin{array}{l}159.9 \pm 15.8 \\
204.4 \pm 11.0\end{array}$ & $\begin{array}{l}162.1 \pm 10.0 \\
163.3 \pm 5.4\end{array}$ \\
\hline$s-\mathrm{TGT}(\mathscr{6})$ & $\begin{array}{l}\text { 前 } \\
\text { 後 }\end{array}$ & $\begin{array}{l}37.4 \pm 2.4 \\
43.8 \pm 3.5\end{array}$ & $\begin{array}{l}37.2 \pm 1.8 \\
37.8 \pm 1.7\end{array}$ & $\begin{array}{l}37.3 \pm 1.9 \\
39.6 \pm 3.8\end{array}$ & $\begin{array}{l}37.7 \pm 1.5 \\
39.8 \pm 2.8\end{array}$ \\
\hline$p$-TGT (q) & $\begin{array}{l}\text { 前 } \\
\text { 後 }\end{array}$ & $\begin{array}{l}80.3 \pm 2.7 \\
81.0 \pm 9.8\end{array}$ & $\begin{array}{l}80.1 \pm 4.1 \\
80.8 \pm 10.9\end{array}$ & $\begin{array}{l}79.4 \pm 3.6 \\
75.6 \pm 9.5\end{array}$ & $\begin{array}{l}78.4 \pm 3.3 \\
70.5 \pm 10.2\end{array}$ \\
\hline $\mathrm{Fbg}(\mathrm{mg} / \mathrm{d} l)$ & $\begin{array}{l}\text { 前 } \\
\text { 後 }\end{array}$ & $\begin{array}{l}507.5 \pm 18.6 \\
508.5 \pm 27.7\end{array}$ & $\begin{array}{l}502.4 \pm 22.3 \\
478.5 \pm 41.4\end{array}$ & $\begin{array}{l}505.1 \pm 19.8 \\
446.8 \pm 33.6\end{array}$ & $\begin{array}{l}503.0 \pm 23.1 \\
428.5 \pm 40.9\end{array}$ \\
\hline $\operatorname{TEG}(r+k)(\mathrm{mm})$ & $\begin{array}{l}\text { 前 } \\
\text { 後 }\end{array}$ & $\begin{array}{l}27.9 \pm 0.2 \\
27.0 \pm 0.6\end{array}$ & $\begin{array}{l}28.0 \pm 0.4 \\
26.7 \pm 0.6\end{array}$ & $\begin{array}{l}28.0 \pm 0.7 \\
26.4 \pm 1.8\end{array}$ & $\begin{array}{l}28.3 \pm 0.9 \\
27.7 \pm 1.3\end{array}$ \\
\hline TEG $\mathrm{ma}(\mathrm{mm})$ & $\begin{array}{l}\text { 前 } \\
\text { 後 }\end{array}$ & $\begin{array}{l}64.6 \pm 2.0 \\
68.1 \pm 2.3\end{array}$ & $\begin{array}{l}64.0 \pm 1.5 \\
68.8 \pm 2.3\end{array}$ & $\begin{array}{l}64.9 \pm 1.7 \\
66.6 \pm 2.4\end{array}$ & $\begin{array}{l}64.5 \pm 1.4 \\
63.7 \pm 2.5\end{array}$ \\
\hline $\mathrm{TC}(\mathrm{mg} / \mathrm{d} l)$ & $\begin{array}{l}\text { 前 } \\
\text { 後 }\end{array}$ & $\begin{array}{r}89.3 \pm 19.3 \\
295.8 \pm 34.5\end{array}$ & $\begin{array}{r}86.8 \pm 15.4 \\
342.5 \pm 19.7\end{array}$ & $\begin{array}{r}84.2 \pm 16.5 \\
173.8 \pm 24.4\end{array}$ & $\begin{array}{r}83.7 \pm 10.7 \\
117.5 \pm 20.0\end{array}$ \\
\hline $\mathrm{TG}(\mathrm{mg} / \mathrm{d} l)$ & $\begin{array}{l}\text { 前 } \\
\text { 後 }\end{array}$ & $\begin{array}{r}82.3 \pm 24.7 \\
219.0 \pm 28.2\end{array}$ & $\begin{array}{r}81.5 \pm 18.6 \\
281.3 \pm 24.8\end{array}$ & $\begin{array}{r}83.6 \pm 15.5 \\
135.6 \pm 21.6\end{array}$ & $\begin{array}{l}80.9 \pm 10.6 \\
82.3 \pm 19.9\end{array}$ \\
\hline $\mathrm{PL}(\mathrm{mg} / \mathrm{d} l)$ & $\begin{array}{l}\text { 前 } \\
\text { 後 }\end{array}$ & $\begin{array}{r}88.2 \pm 11.6 \\
181.3 \pm 13.9\end{array}$ & $\begin{array}{r}85.3 \pm 14.5 \\
239.5 \pm 25.7\end{array}$ & $\begin{array}{r}84.7 \pm 8.4 \\
135.6 \pm 8.1\end{array}$ & $\begin{array}{l}86.4 \pm 10.9 \\
90.3 \pm 14.3\end{array}$ \\
\hline
\end{tabular}

mean $\pm S . D$ 


\section{4）大動脈㢻状硬化症の検索}

実験開始後 4 力月で屠殺, 解剖し, 大動脈起始部力 ら腸骨動脈分岐部まで全長を取り出し, 繸に切り開 き, ホルマリン固定後, Sudan III 染色にて肉眼的に 弹状斑を観繁した。

倨状硬化の強さを客観的に比較するため，Munro $ら^{25)}$ の基準を用い, 変化のもっとも著明な大動脈起始 部につき判定を行った。 すなわち，值径 $0 \sim 1 \mathrm{~mm} の$ 䉼状斑が不連続に少数みられるウサギに1点, 直径 1 〜2 mm のものがかなり多数あるウサギに 2 点, 直径 2 4 mm のものが無数あるウサギに 3 点, 大きな融 合性の斑がみられるウサギに 4 点, 潰演を伴う広筙囲 の斑形成がみられたウサギに 5 点を与え, 各群に属す るウサギにつき得点を合計し，平均值で比較した．

\section{成艘}

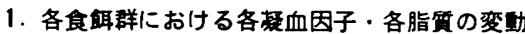

前述のごとく，6週末まではアロキサン静注による 肝騰障害の影䇾の可能性があるので，8 週，10 週，12 週に測定を行ったが, 各食䬣群ともこれら 3 回の值に それほどの差がなかったので，その平均値と各食餉投 与前の値を比校した。なお，表現を简潔にするため， この 8 週, 10 週, 12 週の平均值を “投与後の值” と いうことにする.

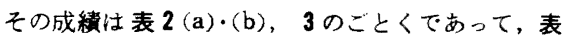
2 (a) ・ (b) に各食慨群における投与前後の平均值およ び標準偏差を, 表 3 に投与前後における有意の変動の 有無を示す.

（1）各凝血因子について

まず F 群においてはすべての凝血因子につき有意の 克進がみられた。 ( $\mathbf{r}+\mathbf{k})$ は有意の短縮を示したが, これは凝血能の元進を意味するものである. 次にL群 では Quick 值と s-TGT を除くすべてに有意の元進

$$
\text { (319) }-19-
$$

がみられたが，P群で有意の充進を示したのは Koller 值と $p$-TGT のみであり， ma はかえって有意の縮小 を示した. N群では Koller 值, V, VII, p-TGT に 有意の䒕進がみられた。

これに対し，非 DM ウサギにおけるこれら諸值の 変動は，DM ウサギに比すれば軽度であったが，それ でもF群, L群ではかなり多数の因子で有意の充進が みられた。しかし，L群で Quick 值が有意の低下を きたしたのは意外の成績であった。

（2）各脂質について

表 2 (a)・(b)，3に示すように，DM ウサギはすべ ての食慨群において TC, TG, PLいずれも有意の增 加を示し, 非 DM ウサギでもN群の TG と PL を除 けば,すべてに有意の増加がみられた。

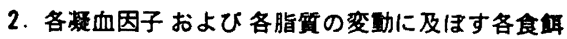 の影雪の比較}

以上のごとく，各食䬣は凝血因子および脂質に対し 有意の影牟を及ぼすが，それぞれの凝血因子ならびに 脂犋に対し，どの食餌の影響が強く，どの食餌の影䛓 が弱いかの比較を行った成績を次に述べる。

（1）各凝血因子についての比較

表了にみられるよらに, 各凝血因子の変動は各食䬣 群によってかなり異なる.よって図 2 に示すごとく, 投与前の值を 100 とし, 投与後 8 週, 10 週, 12 週の 3 回の测定値の平均值との差を変化率として表わし, 各食䬣群について比較した。

i ）Quick 值：DM ウサギにおいては図 2 (a)に 示すように, $\mathrm{F}$ 群においてもっとも著明な上年を示し， $\mathrm{L} \cdot \mathrm{P} \cdot \mathrm{N}$ 各群との間に有意の差があった.

これに対し、非 DM ウサギではやはり F群がもっ とも著明な上昇を示したが，上群はかえって低下を示 し, $\mathrm{F}$ 群・ $\mathrm{P}$ 群と L 群の間に有意の差が証明された。

表 3 各食鲰投与後の数血因子および脂貎の変動

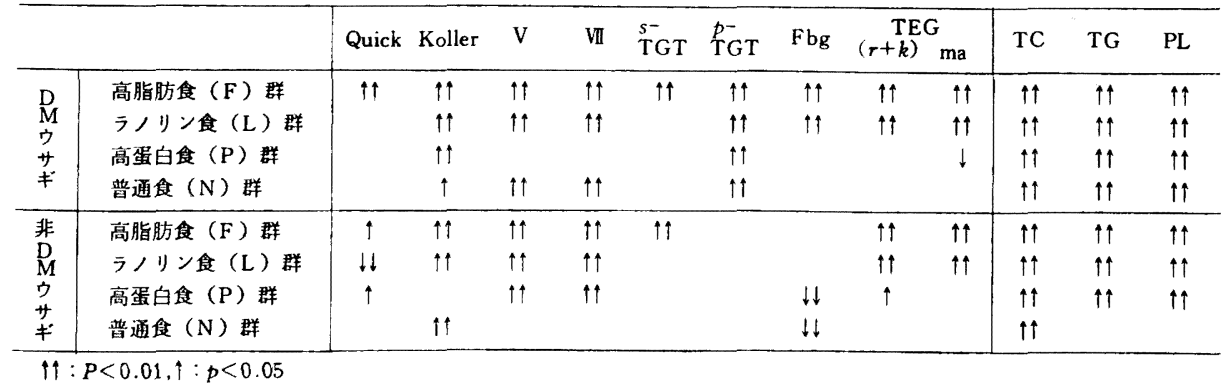



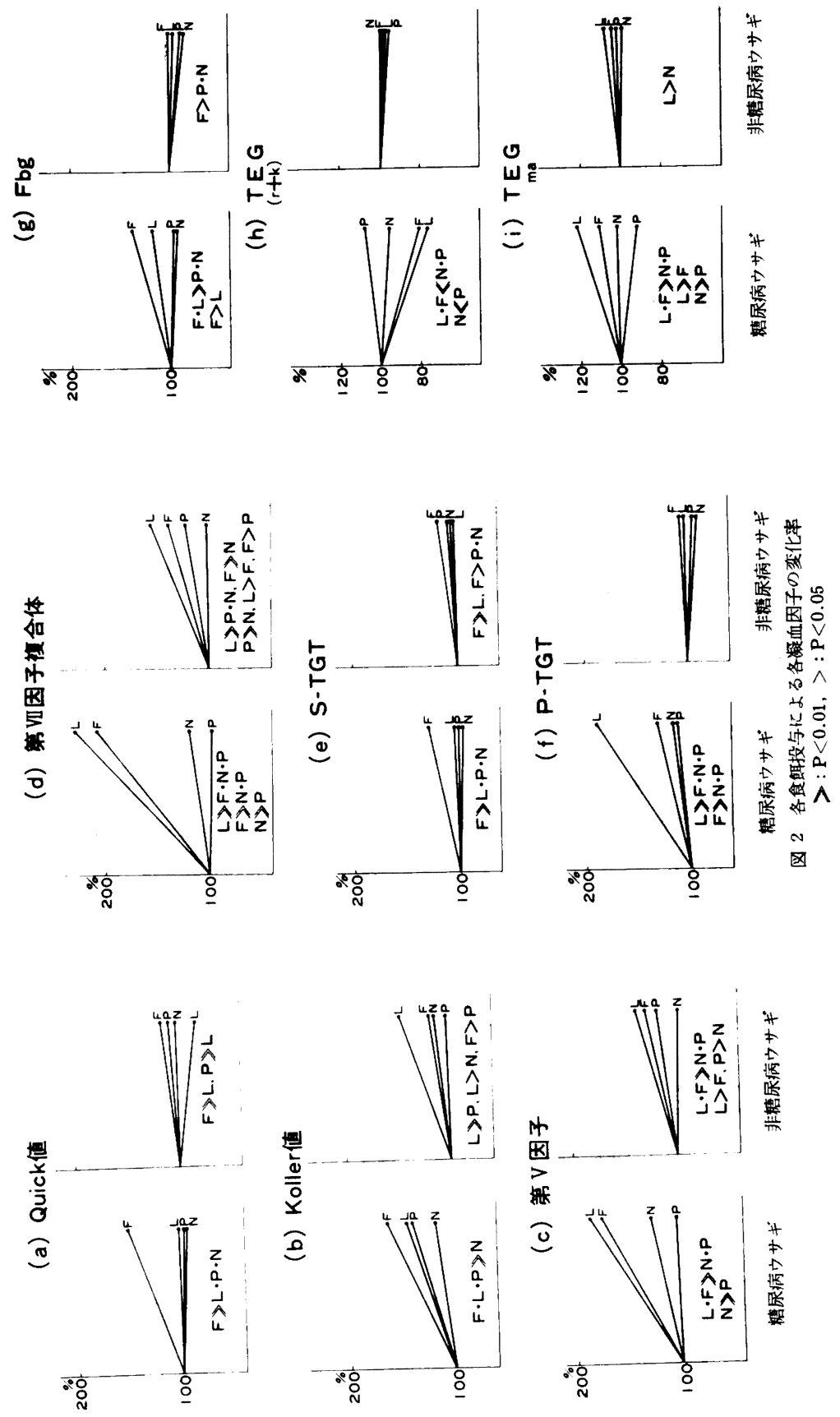
ii) Koller 值 : 図 2 (b) にみられるように DM ウ サギに括いては，F群がもっとも高い上㫒を示し， L 群, $\mathrm{P}$ 群, $\mathrm{N}$ 群の順であった. F.L.P 各群と $\mathrm{N}$ 群の 間に有意の差があった.

この関係は非 DM ウサギではやや異なり，L群, $\mathrm{F}$ 群, $\mathrm{N}$ 群, $\mathrm{P}$ 群の順であり, $\mathrm{L}$ 群と $\mathrm{P}$ 群・ $\mathrm{N}$ 群, $\mathrm{F}$ 群と $\mathrm{P}$ 群の間に有意の差があった。

iii）第V因子：図 2(c) のごとく，DM ウサギで はL群とF群がともに著明な上昇を示し, $\mathrm{N}$ 群, $\mathrm{P}$ 样 との間に有意の差があった。なお，N群における上年 はP群より有意であった。

非 DM ウサギではL群がもっ上も著明に上昇し, しかも第 2 位の $\mathrm{F}$ 群との間に有意の差があった. L 群, $\mathrm{F}$ 群と $\mathrm{N}$ 群・P群の間, $\mathrm{P}$ 群と $\mathrm{N}$ 群の間にも有意の差 があった。

iv）第VII因子複合体：図 2 (d) のごとく、DM ウ サギではL群とF群が著明に上䄯し，次いでN群で怪 度の上昇がみられたが，P群でははとんど不変であっ た. L 群・F 群と N 群・P群の間に有意差が認められ， L群と F 群, N群と $\mathrm{P}$ 群の間にも有意差があった。

これに対し非 $\mathrm{DM}$ ウサギでは L 群, F 群, $\mathrm{P}$ 群, N群の順に上年し, それぞれの群の間に有意差が琶め られた。

v) TGT : s-TGT については, 図 2 (e) のごと く, DM ウサギ, 非 DM ウサギともにF 群において 著明な上型がみられ，他の 3 群との間に有意の差があ った.

これに対しp-TGT は，図 2 (f) にみられるよう に, 非 DM ウサギでは各群ともほとんど変動を示さ なかったが，DM ウサギではL群がもっとも著明に上 昇し，他の 3 群との間に有意の差があった．次いで $F$ 群, N群, $\mathrm{P}$ 群の順であった。 なお, $\mathrm{F}$ 群と $\mathrm{N}$ 群, $\mathrm{P}$ 群との間にも有意の差があった。

vi）フィブリノーゲン：図 2 ( $(\mathrm{g})$ のごとく $\mathrm{DM}$ ウ サギではF群がもっ上も著明に上昇し，L群がこれに つぎ，いずれもP群，N群との間に有意の差があった。 なお，F群とL群との間にも有意の差がみられた。

一方, 非 DM ウサギにおいては，F群の上昇は軽 度ではあったが, 他の 3 群ではかえって低下を示し, $\mathrm{F}$ 群と $\mathrm{P}$ 群およびN群の間に有意の差が認められた.

vii) TEG : $(\mathrm{r}+\mathrm{k})$ 值は, 図 $2(\mathrm{~h})$ のごとく, DM ウサギでは L 群, $\mathrm{F}$ 群, $\mathrm{N}$ 群の順に短縮 (凝血能䒕 㕠)を示し，P群ではむしろ延長するのがみられた。 L群・F群と N 群・P 群の間, N群と P 群との間に有
(321) $-21-$

意差があった。これに対して非 DM ウサギ各群間に は差がなかった。

また，ma 值は，図 2 (i) に示すように, DM ウサ ギでは L 群, $\mathrm{F}$ 群, $\mathrm{N}$ 群, $\mathrm{P}$ 群の順に大きく, 各群の 間に有意の差があった．非 DM ウサギではL群とN 群の間に有意の差があった。

（2）各脂犋についての比較

前節におけると同様の比較を各脂質についても行。 た.その成績を図 3 に示す.

i) 総コレステロール：図 3 (a) のごとくに, D $\mathrm{M}$ ウザではL 群, $\mathrm{F}$ 群, $\mathrm{N}$ 群, $\mathrm{P}$ 群の順に著明な上 梨を示し、この順番に各群の間に有意の差があった。 これに対し非 DM ウサギではL群, F 群, P 群, N群の順を示し，それぞれの間に有意の差があった。

ii ) トリグリセリド：図 3(b) のごとく，DM ウ サギに㧍ける TG 值の変動は TC とまったく同様の 態度を示した．また，非 DM ウサギにおける TG 値 の変動も TC と同様であり，ただ有意差のレベルた多

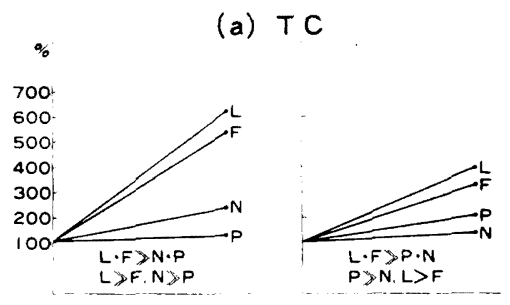

(b) T G

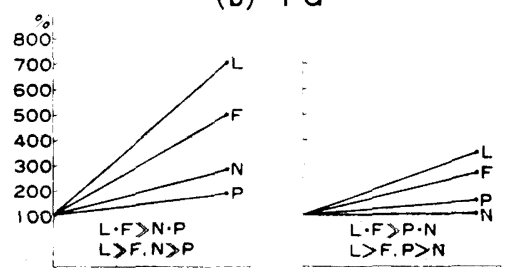

(C) P L
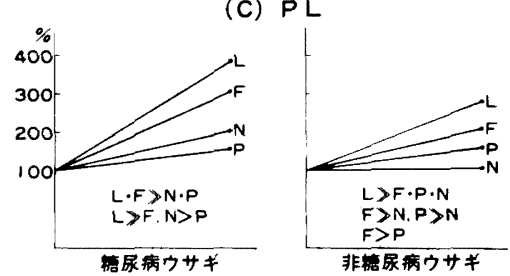

因 3 各食飰投与による各血中脂質の変化率 $>: P<0.01,>: P<0.05$ 
$-22-(322)$

少の差があるのみであった。

iii）爟脂䓄：図 3 (c) のごとく，DM ウサギにお いても，非 DM ウサギにおいても，TC および TG 之同し態度を示し, 各食䬱群間の差の有意水淮に多少 の差があるのみであった。

なお，TC，TG，PLいずれについても DM ウサギ 上非 DM ウサギでP群と N群の順序が逆になること が注目された。

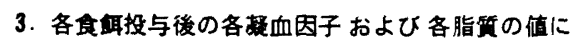
ついて

（1）楮尿病ウサギと非桾疗病ウサギの間の比較 各食期投与によるそれぞれの凝血因子および脂梊の 変動は前節に述べたごとくであるが，動脈硬化の発生 には各食聑投与後に拈けるこれらの做そのものが大き く関倸していると考えられる.

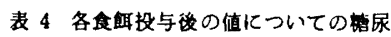
病・非裙尿病ウサギの比交

\begin{tabular}{|c|c|c|c|c|}
\hline & F 群 & L 群 & P 群 & N群 \\
\hline Quick & $\mathrm{P}_{\mathrm{M}} \gg \frac{\text { 非 }}{\mathrm{M}}$ & $\begin{array}{c}\mathrm{M} \\
\mathrm{M}=\underset{\mathrm{N}}{\mathrm{D}} \\
\mathrm{M}\end{array}$ & 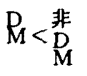 & $\mathrm{M}=\stackrel{\text { 非 }}{\mathrm{M}}$ \\
\hline Koller & $\gg$ & $=$ & $\gg$ & $=$ \\
\hline V & $\gg$ & $\gg$ & $=$ & $\gg$ \\
\hline VII & $\gg$ & $\gg$ & $\ll$ & $\gg$ \\
\hline$s-\mathrm{TGT}$ & $>$ & $=$ & $=$ & $<$ \\
\hline$p$-TGT & $\gg$ & $\gg$ & $\gg$ & $\gg$ \\
\hline Fbg & $\gg$ & $\gg$ & $>$ & $>$ \\
\hline \begin{tabular}{l|l}
$\mathrm{T}$ & $(r+\mathrm{k})$
\end{tabular} & $\ll$ & $\ll$ & $\gg$ & $=$ \\
\hline \begin{tabular}{l|l}
$\mathrm{E}$ & $\mathrm{ma}$
\end{tabular} & $\gg$ & $\gg$ & $\ll$ & $=$ \\
\hline TC & $\gg$ & $\gg$ & $\ll$ & $\gg$ \\
\hline TG & $\gg$ & $\gg$ & $=$ & $\gg$ \\
\hline PL & $\gg$ & $\gg$ & $=$ & $\gg$ \\
\hline
\end{tabular}

表4は、これら各食䬣投与後の值を，DM ウサギと 非 DM ウサギについて比較した成績であって，まず F群とL群的いては，V，VII, p-TGT, Fbg, ma 注 いずれも非 DM ウサギょり $D M$ ウサギにおいて有 意の高値を示し， $(\mathrm{r}+\boldsymbol{k})$ は有意の低值を示した。こ れらは，DM ウサギは非 DM ウサギに較べ，凝血能 兄進状態にあることを示す. かっ TC, TG, PL も DM ウサギにおいて有意に高かった。なお，Quick 值, Koller 值, s-TGT についてはF 群においてのみ DM ウサギが高値を示した.

これに対しP群においては，Koller 值，p-TGT， Fbg は DM ウサギにて大きく，Quick 值，VII, ma および TC は非 DM ウサギの方が高值を示し, $(\mathrm{r}+$ k）は有意に小さかった.

また，N群については V, VII, p-TGT, Fbg, TC, TG, PL は DM ウサギにおいて有意の高值がみられ たが，s-TGT のみは非 DM ウサギが高值を示した.

（2）糖尿病および非榙尿病ウサギそれぞれにおけ る各食餉の影翠の比較

次に，各食慨投与後のそれぞれ凝血因子および脂所 の値を, 大きさの順にならべたデータを表 5 に示す. 有意差の証明されなかった個所は（）をもって表 わし、またかなりの差があるが，例数過少のため有意 性が証明されなかったと思われる個所は（ミ）をもっ て示した。

炭 5 各数血因子およひ脂雷についての食咱群の䐓位

\begin{tabular}{|c|c|c|}
\hline & 槽尿病ウサギ & 非寉尿病ウサギ \\
\hline Quick & $\mathrm{F}>\mathrm{L}=\mathrm{P}=\mathrm{N}$ & $\mathrm{F} \geq \mathrm{P} \geqq \mathrm{N} \geq \mathrm{L}$ \\
\hline Koller & $\mathrm{F}>\mathrm{L}=\mathrm{P}>\mathrm{N}$ & $L \geqq F=N>P$ \\
\hline V & $L=F>N>P$ & $\mathrm{~L}>\mathrm{F}>\mathrm{P}>\mathrm{N}$ \\
\hline VII & $L>F>N>P$ & $\mathrm{~L}>\mathrm{F}>\mathrm{P}>\mathrm{N}$ \\
\hline$s-\mathrm{TGT}$ & $\mathrm{F}>\mathrm{L}=\mathrm{P}=\mathrm{N}$ & $\mathrm{F}>\mathrm{N}=\mathrm{P}=\mathrm{L}$ \\
\hline$p-T G T$ & $\mathrm{~L}>\mathrm{F}>\mathrm{P}=\mathrm{N}$ & $\mathrm{F}=\mathrm{L}>\mathrm{P}>\mathrm{N}$ \\
\hline $\mathrm{Fbg}$ & $F>L>P=N$ & $F \geqq L \geq P \geq N$ \\
\hline$T \mid(r+k)$ & $\mathrm{L}<\mathrm{F}<\mathrm{N}<\mathrm{P}$ & $\mathrm{N}=\mathrm{F}=\mathrm{L}=\mathrm{P}$ \\
\hline \begin{tabular}{l|l}
$\mathrm{E}$ & $\mathrm{ma}$ \\
$\mathrm{G}$
\end{tabular} & $\mathrm{L}>\mathrm{F}>\mathrm{N}>\mathrm{P}$ & $\mathrm{L}=\mathrm{F}>\mathrm{P}>\mathrm{N}$ \\
\hline TC & $\mathrm{L}>\mathrm{F}>\mathrm{N}>\mathrm{P}$ & $\mathrm{L}>\mathrm{F}>\mathrm{P}>\mathrm{N}$ \\
\hline TG & $\mathrm{L}>\mathrm{F}>\mathrm{N}>\mathrm{P}$ & $\mathrm{L}>\mathrm{F}>\mathrm{P}>\mathrm{N}$ \\
\hline$P L$ & $L>F>N>P$ & $\mathrm{~L}>\mathrm{F}>\mathrm{P}>\mathrm{N}$ \\
\hline
\end{tabular}

まず注目されるのは，DM ウサギではし群が首位を 占めたものの多いことである。非 DM ウサギにおい ても，Quick 值や $s$-TGT についてはL 群が最低值を 示したけれども，他の多くの項目ではやはり L群が首 位にあった。

各凝血因子、脂質とも第 2 位はF 群が多かったが; 第了位を占めたのは DM ウサギにおいてはN群であ り，非 DM ウサギにおいてはP群であるといら注目 すべき関係がみられた。

\section{（3）各食慨群の総合的比校}

表4,5にみられるように, 各凝血因子, 各脂所の値 は，投与された食饂の種類によって異なる。この点を さらに検討するため，例え壮各食期群におけるQuick 值と TC の関係をしらべると，DM ウサギにおいて は, 图4(a) に示すようにL群が左上に，F群がその 右下に，N群がその左下に，もっとも下にP群がプロ ットされ，各群間にほとんどオーバーラップのないの がみられた。

これに対し非 DM ウサギにおいては，图4(b)に 
示ナよ5にL群は左上に, F群は右上に, その下に $\mathrm{P}$ 群が,もっとも下にN群がブロットされた．ある程度 のオーバーラップはみられたが，かなりょく分離され ているといってよかろう。

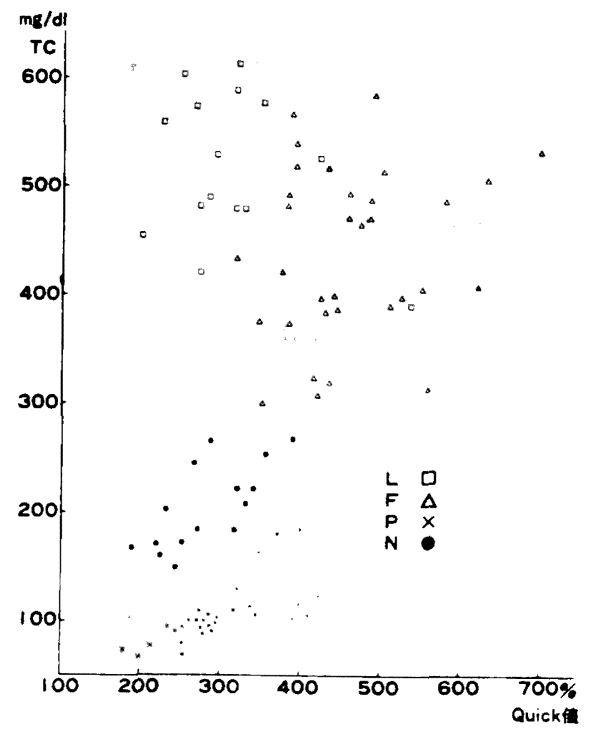

困 4 (a) 捾尿病ウサギにおける Quick 值と

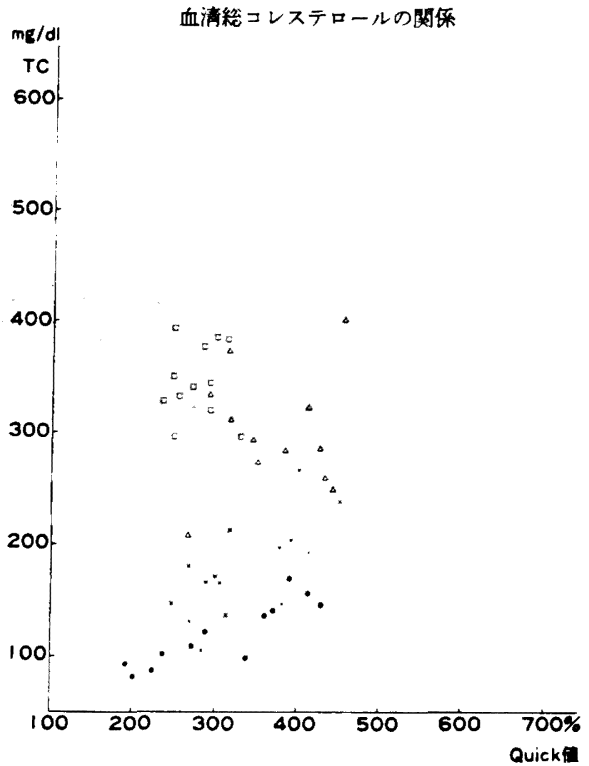

因 4 (b) 非蛒尿病ウサギにおける Quick 值と 血潔給コレステロールの関係
ほぼ同様の関係が，他のほとんどすべての組合せで もみられた.このことは,これら 4 食辆群の間に凝血 能および脂梊に関し総合的な差があることを示唆す る.この点を明らかにするため, 以下の推計学的分析 を行った。

この分析は Hotelling の $T^{2}$ を用いても行われ るが，それよりも MANOVA (multivariate analysis of variance) ${ }^{26)}$ を用いる方が能率的であると考えここ の方法を操用した。この方法を用いる時には, 個々の 凝血因子あるいは脂犋值ではなく，それらを総合して 各群間の比䖝がなされる．かつ各群間に有意の差があ るかどうかを検定するには, Wilks の尤度比テスト を用いればよい，具体的には次の式

$$
x_{H}^{2}=-\left\{\nu_{E}-\frac{1}{2}\left(p-\nu_{A}+1\right)\right\} \log _{E} U_{H}
$$

を計算して $x^{2} H$ の值を求め， $\chi^{2}$ 分布を用いて検定を 行うことになる.ここで

$$
U_{H}=\frac{\left|Q_{E}\right|}{\left|Q_{H}+Q_{E}\right|}, \quad \nu_{A}=m-1, \quad \nu_{E}=n-m
$$

$Q_{H}$ は群間平方和・㮴和行列, $Q_{E}$ は残差に対する平 方和・積和行列, $n$ は実験数, $m$ は実験群の数, $p$ は 変量 (検査項目) の数である.

この方式を用いるなら，4つの食䬣群における差を 同時に検討することができる、実際にこの式を計算し てみたところ, DM ウサギに関しては

$$
\begin{aligned}
& U_{H}=0.8348 \times 10^{-4} \\
& \chi^{2}{ }_{H}=206.6003 \\
& p<0.01
\end{aligned}
$$

といら成績がえられた．ただしこの成綘は 4 群間に有 意の差が存在することを示すのみで, 個々の群間につ いては, 改めてそれぞれの 2 群についての比嘍を行な わなければならない，このさいにも MANOVAを用 い,まず $\mathrm{P}$ 群と N群についてしらべると，

$$
\begin{aligned}
& U_{H}=0.1800 \\
& \chi^{2}{ }_{H}=36.0057 \\
& p<0.01
\end{aligned}
$$

また $\mathrm{F}$ 群と $\mathrm{P}$ 群の間については

$$
\begin{aligned}
& U_{H}=0.1154 \times 10^{-1} \\
& x^{2}{ }_{H}=93.7038 \\
& p<0.01
\end{aligned}
$$

といら結果がえられた。なお, 実呀数にN群と $\mathrm{L}$ 群は 5 例, F 群は 11 例, $\mathrm{P}$ 群は 10 例とい5違いがあっ たが，その点については各群の例数にしかるべき係数 をかけたさい，その和が 0 になるような倸数を用いれ ばよいといら方式によって補正を行った。 
$-24-(324)$

次に非 DM ウサギについても同様の検定を行い， 全 4 群については,

$$
\begin{aligned}
& U_{H}=0.4455 \times 10^{-5} \\
& \chi^{2}{ }_{H}=98.5711 \\
& p<0.01
\end{aligned}
$$

P群と N群の間では

$$
\begin{aligned}
& U_{H}=0.1795 \times 10^{-1} \\
& \chi^{2}{ }_{H}=28.1400 \\
& p<0.01
\end{aligned}
$$

$\mathrm{P}$ 群と $\mathrm{F}$ 群の間では

$$
\begin{aligned}
& U_{H}=0.7667 \times 10^{-2} \\
& x^{2}{ }_{H}=34.0954 \\
& p<0.01
\end{aligned}
$$

という結果がえられ, それぞれ有意の差が証明され た.

ところがさらに DM 群と非 DM 群に区分せず, 実験ウサギ全体につき同様の比較を行うと，全 4 群間 については

$$
\begin{aligned}
& U_{H}=0.6029 \times 10^{-2} \\
& \chi^{2}{ }_{H}=199.3378 \\
& p<0.01
\end{aligned}
$$

となり, 有意の差のあることが知られたが, $\mathrm{P}$ 群と $\mathrm{N}$ 群の間では

$$
\begin{aligned}
& U_{H}=0.7223 \\
& \chi^{2}{ }_{H}=12.3642 \\
& p: \text { n.s. }
\end{aligned}
$$

となり, 両者の間に有意の差のないことが示された.

たたしL群とP群，F群とP群の間については

$U_{H}=0.9295 \times 10^{-1}$

$\chi^{2}{ }_{H}=90.2761$

$p<0.01$,

$U_{H}=0.7501 \times 10^{-1}$

$\chi^{2}{ }_{H}=98.4243$

$p<0.01$

となり，それぞれ有意の差のあることが証明された.

すなわち，DM ウサギおよび非 DM ウサギのそれ

\begin{tabular}{|c|c|c|c|c|}
\hline \multirow[b]{2}{*}{$\begin{array}{l}\text { 高脂肪食 } \\
(\mathrm{F}) \text { 群 }\end{array}$} & \multicolumn{2}{|c|}{ 胡尿病ウサギ（平均） } & \multicolumn{2}{|c|}{ 非糖尿病ウサギ（平均） } \\
\hline & 11 羽 & $\begin{array}{l}2,2,2,3,2,3 \\
3,3,2,2,2(2,4)\end{array}$ & 4 羽 & $\begin{array}{l}2,1,1,2 \\
2(1.8)\end{array}$ \\
\hline $\begin{array}{l}\text { ラノリン食 } \\
\text { (L)群 }\end{array}$ & 5 & $4,4,4,3,4(3.8)$ & 4 & $\begin{array}{l}3,3,2 \\
2(2.5)\end{array}$ \\
\hline $\begin{array}{l}\text { 离蛋白食 } \\
(\mathrm{P}) \text { 群 }\end{array}$ & 10 & $\begin{array}{l}0,0,0,0,0.1 \\
1,0,0,0(0.2)\end{array}$ & 5 & $\begin{array}{l}1,0,1 \\
1,0(0.6)\end{array}$ \\
\hline $\begin{array}{l}\text { 紫通食 } \\
(\mathrm{N}) \text { 群 }\end{array}$ & 5 & $0,0.1,1,1(0.6)$ & 4 & $\begin{array}{l}0,0,0 \\
0(0)\end{array}$ \\
\hline
\end{tabular}
ぞれについて検討したさいには，P群とN群の間に有 意の差がみられたのに，DM ウサギと非 DM ウサギ を合せて検乱したところ，両食䬣群の間には差が見出 されなかった．このことは，DM ウサギと非 DM ウ サギとで $\mathrm{P}$ 群と $\mathrm{N}$ 群の順序が逆であることを意味す る. 表 5 の成績からみて、DM ウサギにおいてはN 群・ $\mathrm{P}$ 群の順, 非 DM ウサギにおいては $\mathrm{P}$ 群・ $\mathrm{N}$ 群 の順であると推論される。

\section{4. 榶尿病および非范㽷病ウサギ各食聑群における} 大動脈煍状硬化の発生についての検索

実験方法の項で述べた採点法にしたがって，個々の ウサギにつき採点した成綪を表 6 に示す.

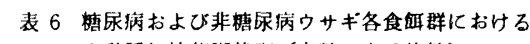
大動服起始部弱状班（点数による比攺）

まず DM ウサギについては，L 群において砵状斑 の生成がもっとも著明であり, ついで F群, N群, P 群の順に軽度となった。 この関係は非 DM ウサギで もほぼ同梯で，L群にもっとも著明で，次いでF群で あったが，DM ウサギ上巽なり，P样より N群の方が 軽く、生成がまったくみられなかった，なお，L群， F 群それぞれにつき DM ウサギと非 DM ウサギに おける粥状斑の程度を較へると，DM ウサギにおいて より強いのがみられた。

\section{考察}

\section{1. 臨床的およひ実験的榶尿病と正常対照の間にお} ける疑血能の差

糖尿病臨床例の凝血能については, 著者の共同研究 者国島”および佐竹ら”店研究を始めとしてかなり多 くの人々の報告があるが，それらの成績は必ずしも一 致していない，しかもこの問題を動物実駼により検郡

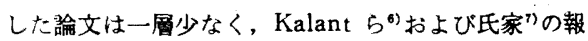
告をみるにすぎない。

本碖文に㧍ける著者の研究目的は，DM ウサギに対 寸る各種食䭒の影警をしらへることにあるが, 表 4 の 右端に示した普通食飼育のデータは、ここで討論して いる問題に対する答えにほかならない.いかかえると このデータは著者の研究の副産物にすぎないが，まず この問題から検討を行らことにし，項目順に考察を加 えてみる.

Quick 值: DM 臨床例については Lombardi $ら^{27)}$, 松永ら ${ }^{28}$ 流高值をとると報告し富永ら ${ }^{289}$, 松永ら ${ }^{301}$ は 低下の傾问を示すと述べているが, Egeberg ${ }^{3)}$, 氏家” のごとく変化なしとする人もある，国島"，佐竹ら 
は，薬物によるコントロールを必要とした群は，食事 療法のみによりコントロールされた群より，有意の高 做を示したと述ぺている．著者の動物実験では DM ウサギと非 DM ウサギの間に有意の差がなかった.

Koller 值: 臨木例について国島“), 佐竹ら 家》 は正常簀囲にあったと報告している，著者の動物 実験でも両者の間に差がなかった。

第V因子活性值：DM 臨床例では高值を示すという 報告9)，正常もしく渷値をとる傾向にあったという 報告( ${ }^{45}$, 正常対照に比し有意の差がなかったという報 告”があり，一致していない，著者の実験成績では， DM ウサギにおいて有意の高値がみられた。

第䜣因子複合体活性値：DM患者ではえ進がみられ たといら報告が多く4,5,7,31), 合併症のない糖尿病では 正常だったが網膜症・堅症・ケトアチドーシスを合併 した例では高値を示したという報告もある”。

実験的 DMについては氏家”は有意の活性上昇がみ られたと述へており，著者の成倕でも有意差があっ た.

血清トロンポプラスチン形成能: 国島(),佐竹ら 柽症 DM では高値を示すものが少ないと述べている が，第IX因子を測定したEgeberg ${ }^{3)}$ 泣正常範囲内にあ ったと記载している. 著者の成績では DM ウサギに 校べ非 DM ウサギでむしろえ進しているという関倸 がえられた。

吸着血装トロンボプラスチン形成能 : 国島”, 佐竹

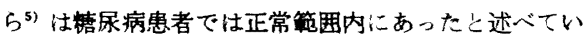
るが, Egeberg ${ }^{3)} や$ Mayne ら ${ }^{32}$ 注臨床例において第

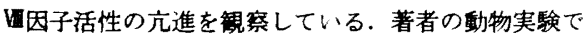
は非 DM ウサギより DM ウサギにおいて有意の充 進がみられた。

血采フィブリノーゲン：DM 患者における Fbg の 増量は多くの人々により報告されているが ${ }^{3,32}$,糖尿病 性堅症・網膜症などの血管障害合併例あるい仕非軽症 例のみで増量が認められたという人もある 著者の動物実験成績では DM ウサギが非 DM ウサ ギより有意の高値を示した。

TEG : かなり多数の人々により $(\mathrm{r}+\mathrm{k})$ の短縮と $\mathrm{ma}$ 幅の増大が臨床例について観察されており, 糖尿病に おける凝血能六進状態が指摘されている4,5,27,34-38). ただし䍜病期間その他の因子により差があったとする 人と，差がなかったとする人がある. 著者の動物実験

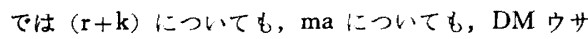
ギと非 DM ウサギの間に有意差はなかった.
(325) $-25-$

以上を総括すると，著者のウサギにおける実験的デ 一夕は，多少くいちがいはあるけれども，DM臨床例 における所見とおおむね一致したといってよかろう。

2. 傛尿病および非榶尿病ウサギの凝血能に及ぼす 各種食埴の影䈏

研究者によってデータに多少の差沬あるが, DMウ サギにおいて凝血能に変化のおこることは上述のごと くである.よって次に，各種の食䬺が凝血能に対して いかなる影製を与えるかをしらべてみた，かかる研究 は，著者の知るかぎりでは，まだ行われていない，

その成䋖は表 3 に示すごとくであって, 高脂肪食も しくはラノリン食は DM ウサギにおいても非 DM ウ サギにおいても，各凝血能に対しかなり促進的にはた らいていることが観祭された.

これと似たような実験を Kalant ら゙も行っており， アロキサン DM ラットと正常ラットを高脂肪食にて 飼育し，両ラットにおいてプロトロンビン時間の短 縮, II, V, VII, UII, X 因子活性元進, アンチトロンビ ンの減少がみられたと述べている.

著者はさらに高蛋白食の影響についてもしらべてみ たところ，DM ウサギでは Koller 值および p-TGT に対してのみ促進的にはたらき，ma はかえって有意 の縮小をきたすといら成績がえられた。

次にこれらの食餪が凝血能に及ぼす影響を DM ウ サギと非 DM ウサギで較べてみた。 その成績は表 4 に示すごとくであって，まずN群にあっては，V，VII， $p$-TGT, Fbg は DM ウサギにおいて非 DM ウサギ より有意の高值を示したが， $s$-TGT はむしろ非 DM ウサギの方が高かった。

これに対しF群ではすべての因子につき DM ウサ ギが非 DM ウサギより有意の高值を示し $((\mathbf{r}+\mathbf{k})$ の み低值), 凝血能立進の一層著明なことが認められた。 L 群も, Quick 值, Koller 值およびs-TGT を除け ば， $\mathrm{F}$ 群とほとんど同じ状態にあった。

ところがP群では, Koller 值, p-TGT, Fbg は DM ウサギの方が非 DM ウサギより高かったが, Quick 值, VII 沙対に低值を示し, かつ TEG 所見 も $\mathrm{F}$ 群や L 群と異なる成績を示した。

さらに個々の凝血因子に対し，どの食䬣の影響がも っとも強く,どの食餉がもっとも弱いかの点につきし らべたところ，表5に示したように，DM ウサギ，非 $\mathrm{DM}$ ウサギともに L 群もしくはF 群が首位を占める のがみられた，注目すべきは，P群とN群を較べる 
$-26-(326)$

と、非 DM ウサギではP 群が高い順位にある場合が 多かったのに対し、DMウサギではむしろ P 群が最下 位を占める場合の多かったことである。

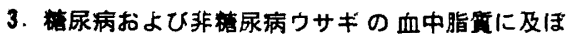
す各程食畘の影零

高脂肪食やラノリン食が血中脂倎の增加をきたすこ とはすでに多くの人々によって観察された事実であ り，著者のデータでも DM ウサギ・非 DM ウサギ を問わず，その所見がみられた，かつ両者を較へる と、 $\mathrm{F}$ 群, L 群ともに TC, TG, PL が $\mathrm{DM}$ ウサギ において高傎を示した。

なお，注目すべきは，TC 傎がN群においては DM ウサギで高値を示したのに対し，P 群では DM ウサ ギの方が低値を示したことである.

さらに表 5 のように各脂啠の值を食慨群別にならへ てみると，いずれの脂得についても非 DM ウサギで はN群が最下位にあったのに対し，DMウサギではP 群が最下位にあるという差がみられた。

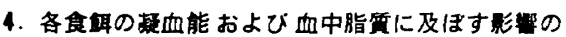 合的検討}

各食慨はそれぞれ凝血能および脂質に影響を与える が，表 5 をみて大体のところをまとめると，DMウサ ギに拈いては

$$
\mathrm{L}>\mathrm{F}>\mathrm{N}>\mathrm{P}
$$

非 DM ウサギにおいては

$$
\mathrm{L} \doteqdot \mathrm{F}>\mathrm{P}>\mathrm{N}
$$

の関係にあるといってよかろう。

著者はこの点をさらに確かめるべく，MANOVA の手法を用いて検郡した。 その結果，DMウサギにつ いても非 DM ウサギについても，4食慨群間に有意 の差があること,またそれぞれの 2 群間にも有意の差 のあることが証明された。

L群やF 群で凝血能や血中脂愋の上昇することは予 期した成績であったが、非 DM ウサギでP群がN群 より高值を示したのに，DMウサギではP 群がN群よ り低い值を示したことは，きわめて興味があり，かつ 重要な所見であるとみなされる。

\section{5. 辉尿病における動脈硬化に対する高蛋白食の意} 荤

表3のごとく，DM ウサギにおいては普通食投与に よっても Koller 值, V, VII, $p$-TGT の上昇をきた
し, TC, TG, PL も増量するのに対し，高蛋白食で はそれほどの変化はみられないといら違いがあった。

さらに表5にみるように，DMウサギにおいてはP 群の方が, 凝血能, 血中脂質についても，N群より低 い值を示し，かつ両群の間に有意の差のあることが， 推計学的に証明された. 非 DM ウサギではかかる関 係はみられず，P群の方がN群より一般に高い值を示 した.

この関係は，大動脈の形热学的検索についても観察 された.すなわち、表6に示したように，DMウサギ における粥状斑の生成は $\mathrm{L}$ 群, $\mathrm{F}$ 群, $\mathrm{N}$ 群の順に著明 にみられ，P群でもっとも㹩度であった。これに対し 非 DM ウサギではN群がもっとも㹩度で, P 群では これより著明であった。

血中脂倎および砥状硬化の発生につき, 蛋白食がこ のような影䇾を有することは，すでにいろいろの人々 により，いろいろの方法により観察，指摘されている ところである. すなわち, ラットについては, Moyer ら"や Fillios ら”は食慨中の蛋白を增すと TC ある いは PL が低下することを述べ，さらに Jones $5^{201}$ やNath $5^{11}$ は，食慨中の蛋白が適当な量のときTC， PL がもっとも低い値を示し，蛋白がそれより多くて も，少なくても，TC，PL は増加したと報告した。 さらにニワトリについては, Kokatnur ら ${ }^{12)}$, Stamler $5^{13)}$, Pick $ら^{14)}$, Nikkilä $ら^{(5)}$ が, ラット におけるとほほ同義的な研究成果を発表しており, イ $ヌ^{16)}$ ，サル に29ついての報告もある.

ただしブタについては，Greer 5(0)によれば，低蛋 白食注 TCを上㫒させ，大動脈粥状硬化発生頻度を高 めたが，冠動脈については反対に高蛋白食の方が広籍 囲に粥状硬化を生したと述べている.ブタのTC 㹥 慨中の蛋白量に影譬されないとの報告もある(1,42).

ヒトについては, Keys ら (3)が食事中の蛋白量を低 值 $(64 \mathrm{~g} /$ 日) 加ら高值 $(138 \mathrm{~g} /$ 日) まで変えてみたが, 血清 TCには何ら影製がみられなかったと述べている のに対し, Olson ら“4) 蛀白量を $100 \mathrm{~g} /$ 日から $25 \mathrm{~g}$ / 日に減少させると TC および $\beta$-リポ蛋白が低下する ことを観察した。しかしいずれも糟尿病患者における 観察ではない。

著者はウサギを用いて実験を行ったが，ウサギを用 いた研究はそれほど多くはない. Meeker ら ${ }^{(5)}$ は実験 的大動脈硬化に対し，大豆を含む高蛋白食は抑制的に はたらいたのに対し，カゼインを含む高蛋白食はかえ って增強したと述べており，また Munro ら ${ }^{25)}$ は 8 
\% 蛋白食と $30 \%$ 蛋白食とで血中 TC の上昇および大 動脈硬化の程度にほとんど差がなかったと報告してい る.

さらに吉岡(6)は, 高脂肪・低脂肪，および高蛋白・ 標準蛋白・低蛋白を組み合わせた食慨によりウサギを 飼育し, 高脂肪食群と低脂肪食群のいずれにおいて も，食餌中の蛋白量の多い群ほど血清 TC, 総脂倎, 総 リンが高值を示すのを観察した.これら Munroら25), 吉岡(日)の観察は，高蛋白食が血清脂梊上㫒ないし動脈 硬化発生に抑制的にはたらくとする上部の多くの研究 報告と異なる.

以上の諸報告を著者のデータと校へると, 著者の成 嚗においては凝血能六進, 脂質上㫒, 動脈硬化いずれ も， DMウサギではN 群よりも $\mathrm{P}$ 群の方が軽度であっ たのに対し, 非 DM ウサギではP 群の方が著明であ った.したがって食慨中の蛋白増量により動脈硬化そ の他が抑えられるという所見は，著者のデータではD M ウサギのみにみられ，非 DM ウサギではみられな

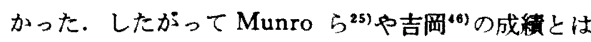
決して矛盾しない.

いずれにしても著者のごとく，DM動物についてこ のような研究を行った報告は意外に少なく，わずかに 増田"7)の論文がみられるだけである，彼はアロキサン 糖尿シロネズミに標準食, 高蛋白食, 高脂肪食, 高蛋 白高脂肪食を 3 力月間与えたところ, 高脂肪食群と高 蛋白高脂肪食群における TC, PL およびェステル型 総脂肪酸值は標準食群より高值を示したが, 高蛋白食 群では標淮食群より低値を示す傾向にあったと述べて おり，著者の研究とほとんど一致する成績である．

なお，DM動物の凝血能に対する食慨の影響をみた 研究としては，すでに言及した Kalant ら の論文を みるのみであり，しかも彼らは高脂肪食のみを対象と し，高蛋白食についてはしらべていない，

高蛋白食のこのような勃果の機序としては, 含硫ア ミノ酸の有するコレステロール合成抑制, ユレステロ 一ルの胆汁酸への転換促進作用などが考えられてい $3^{(8,40)}$ ，一方，低蛋白食による血清 TC 值の上䄯につ いては，長期間の蛋白久乏による肝細胞障害のため, 外因性コレステロールの排泄 (excretion) が堿少する ことなどがあげられる(5).

DM ウサギにおける高蛋白食が, 凝血能六進状態に 对しても抑制的に㑬くという機粠については，現在の 段階におけるわれわれの知識では，5まい説明を見出 すことができない，今後解決すべき問題である.

\section{6. 総括的考察}

凝血能の元進が動脈硬化の一因として大きな役割を 演していることはすでにほとんど定説となっている. 糖尿病における凝血能についてはまだまとまった研究 がなされていないが，やはりその六進状態をみるとい う報告が多く，著者の動物実験でもその充進がみられ た

一方, 血中脂所の増加が動脈硬化の発生にもっとも 重要な役割を演していることは疑う余地はなく，糖尿 病におけるその増量が, 糖尿病に動脈硬化の多い事実 に関係うけられることはいうまでもない。

著者の実験成綞を要約すると，DM ウサギで脂質増 量とともに凝血能の充進のみられること,ラノリン食 や高脂肪食は非 DM ウサギでも脂質增量と凝血能の 六進をきたすが，DMウサギではその程度が一層著明 であったこと，大動脈に㧍ける粏状斑の形成は非 DM ウサギの高脂肪食, ラノリン食飼育でもみられたが, DM ウサギでこれらの食慨を与えたとき一層著明であ ったことなどは，糖尿病における凝血能立進が動脈硬 化の発生に重要な因子として関与していることを示す ものといってよかろう

さらに，DM ウサギにおけるこれらの変化は，高蛋 白食で飼育した場合には軽度であった。このことは, 臨床例においても DM 患者に普通食よりも高蛋白食 を与えることが, 動脈硬化の進展を防ぐのに有用であ ることを教える.

\section{結論}

糖尿病において食慨性因子が血液凝固能, 血管障害 発生にいかなる影警を及ぼすかを，アロキサン糖尿病 ウサギを用いて検郡し，さらに非楉尿病（対照群）ウ サギと比較した. 各食期の投与期間は 12 週とした.

1）アロキサン投与による肝障害は凝血因子の変動 をきたすが，検索の結果，血清醭素值は投与後 6 週間 で正常にもどることが知られたので，これ以後の值は 糖尿病そのものによる変動とみなして検郡を行った。 かっ 8，10，12 週の測定值にそれほど差がなかった ので，それらの平均值を “投与後の值”として採用し た.

2）まず普通食にてアロキサン糖尿ウサギを飼育し たさいの凝血因子の変動については，Koller 值，第 V因子 (V) および第UI因子複合体活性值 (VII)，血浆 トロンボプラスチン形成能 ( $p-T G T)$ て有意の上昇が 
$-28-(328)$

みられたが，トロンバラストグラム (TEG) の諸值な どには明らかな変動はみられなかった。

3）糖尿病ウサギのうち高脂肪食群では検査したす べての項目で, ラノリン食群では Quick 值とs-TGT を除く全項目で有意の充進がみられた。これに対し， 高蛋白食群で有意の立進がみられたのは Koller 值と p-TGT のみであり， ma はかえって縮小を示した.

4）これに対し非糖尿病ウサギでは，糖氺病ウサギ に比すれば軽度であったが, それでも高脂肪食群, ラ ノリン食群ではかなり多数の因子につき凝血能の六進 がみられた。

5）榶尿病ウサギでは各食餪群上も血清総コレステ ロール，トリグリセりド，燐脂質に有意の増加がみら れ，非榶尿病ウサギにおいても普通食群に㧍けるトリ グリセリドと燐脂質が有意の增加を示さなかったのみ で, 他の食䬲群ではいずれも有意の増加がみられた。

6）各食慨の及ぼ影留を糖尿病と非糖尿病少サギ で比較すると, 高脂肪食群では凝血能と脂質の寸へて の項目について糖尿病ウサギが高値を示し, ラノリン 食群では大部分の凝血因子と脂質のすべてについて糖 尿病ウサギが高い值を呈した，高蛋白食群の凝血因子 については糖尿病ウサギが高値を示すものと，かえっ て低值を示すものとあり，脂質については総コレステ ロール值のみ非糖原病ウサギにおいて高かった. 普通 食群では約半数の凝血因子とすべての脂質において桾 尿病ウサギが高値を示した。

7）各食慨による飼育後の值を比較すると, 糖尿病 ウサギでは多くの項目においてラノリン食が首位を占 め, 次で高脂肪食, 普通食の順であり, 高蛋白食は最 下位にあった。これに対し非糖尿病ウサギではラノリ ン食, 高脂肪食, 高蛋白食, 普通食の順を示し, 高蛋 白食と普通食の順が入れかわた。

8）以上の関倸は各食䬣群間心，凝血能および脂質 に関し総合的な差のあることを示唆する。この点を多 変量解析法により分析すると, 糖㽷病ウサギについて も，非糖尿病ウサギについても，4食䬣群間に有意差 のあること, 高脂肪食と商蛋白食, 高蛋白食と普通食 の間にも有意差のあるのがみられた。

9）さらに，糖尿病・非糖尿病ウサギを分けず，全 体につきしらべたところ, 全 4 群間には有意差があっ たが, 高蛋白食と普通食の間には有意差がなかった。 このことは粕尿病ウサギと非糖尿病ウサギで, 両食慨 の順序が逆であることを示し，7）に述べたところよ りみて, 糖尿病ウサギでは普通食・高蛋白食の順, 非
糖尿病ウサギではその逆であると結論される。

10）実辆終了後ウサギの大動脈を肉眼的に検索す ると, 糖尿病ウサギにおける悚状斑の生成はラノリン 食, 高脂肪食, 普通食, 高蛋白食の順に著明であった が，非糖尿病ウサギでは高蛋白食と普通食の順序が入 れかわった。

11）以上を総合し，実験的糖尿病ウサギにおける 動脈硬化の発生には, 脂質とともに凝血能六進の関与 していること，高蛋白食はそれを抑えるようにはたら くことが結論される.

稿を終るに臨み，本研究においてご指道およびご援助をい ただいた臨床病理学教窒の高山弘平教授に深く感䛠いたしま す.さらに, 本研究の統計的分析についてご指導いただいた 埼玉大学保健管理センター所長堂前嫴教授に㳭く感陚い たします。なお，計算にはご好意により北里大学付属病院 KCAM の電算機 YHP 21-MX を使用させていただいた. 䦎係各位に感辢の意を表します。

(本論文の要旨は, 第 5 回日本榶尿病学会地方会, 第10回, 第13回日本老年医紛会学会において発表した.)

\section{文献}

1) Valdorf-Hansen, F.: Thrombocytes and coagulability in diabetics. Dan. Med. Bull., 14, 244, 1967.

2) Giannico, O., and Morrazza, P. : Policlinico (Prat.), 55, 573, 1948.; Progr. Med. (Nap.), 6, 466, 1950. 1) より引用

3) Egeberg, O. : The blood coagulability in diabetic patients. Scandinav. J. Clini, Lab. Investigation, 15, 533, 1963.

4）国島修: 榙尿病比関寸る凝血学的研究. 日医大誌, 31, 8, 1964 .

5）传竹清人，高山弘平，牛山清司，国易修，山绮登志 雄, 盤若博司, 八幡浩二, 中田英策, 棉基实, 田䗁次 男, 酒井義男, 原文男, 市川魅, 大林完二, 藤原忠通： 槽尿病の㠜血障害一とくに hypercoagulable state $の$ 意義について一. 最新医学, 20, 1684, 1965.

6) Kalant, N., Teitelbaum, J.I., and Cooperberg, A.A. : Dietary atherogenesis in alloxan diabetes. J. Lab. Clin. Med., 63, 147, 1964.

7）氏家昭：楉尿病の出血性素因に関する研究. 日血会 诘, 28, 727, 1965.

8) Moyer, A.W., Kritchevsky, D., Logan, J.B., and Cox, H.R. : Dietary protein and serum cholesterol in rats. Proc. Soc. Exp. Biol. Med., 92, 735, 1956.

9) Fillios, L.C., Andrus, S.B., Mann, G.V., and Stare, F.J. : Experimental production of gross atherosclerosis. J. Exp. Med., 104, 539, 1956.

10) Jones, R.J., and Huffman, S. : Chronic effect of dietary protein on hypercholesteremia in the rat. Proc. Soc. Exp. Biol. Med., 93, 519, 1956.

11) Nath, N., Harper, A.E., and Elvehjem, C.A. : Dietary protein and serum cholesterol. Arch. 
Biochem., 11, 234, 1958.

12) Kokatnur, M., Rand, N.T., Kummerow, F.A., and Scott, H.M. : Effect of dietary protein and fat on changes of serum cholesterol in mature birds. J. Nutrition, 64, 177, 1958.

13) Stamler, J., Pick, R., and Katz, L.N. : Effects of dietary proteins, methionine and vitamins on plasma lipids and atherogenesis in cholesterol.fed cockerels. Circ. Res. 6, 442, 1958.

14) Pick, R., Jain, S., Katz, L.N., and Johnson, P. : Effect of dietary protein level on regression of cholesterol-induced hypercholesterolemia and atherosclerosis of cockerels. J. Atheroscler. Res., 5, 16, 1965.

15) Nikkilä, E.A., and Ollila, O. : Effect of low protein diet on the serum lipids and atherosclerosis of cholesterol-fed chickens. Acta. Path., 40, 177, 1957.

16) Li, T., and Freeman, S. : Experimental lipidemia and hypercholesterolemia by protein depletion and cholesterol feeding in dogs. Am. J. Physiol., 145, $660,1946$.

17) Quick, A.J. : Hemorrhagic diseases. p. 379, Lea and Febiger, Philadelphia, 1957.

18) Koller, F., Loeliger, A., and Duckert, F. : Experiments on a new clotting factor (Factor VII). Acta Haematol., 6, 1, 1951.

19）佐竹清人，八幡浩二，盤若博司，中田英策，綿買実: ブロトロンビン定冝法の比較娭討. 日血会誌, 25, 639, 1962.

20）荻原洋三：ブロトロンビンおよび不安定因子に関する 研究. I . 不安定因子の測定法について。信州医誌, 6, $252,1957$.

21）佐竹清人, 盤若博司, 八幡浩二, 中田英策, 綿貫实, 田㥓次男：血液凝固に関する検査法 (3). 臨床梌査, 7, 199, 1963.

22) Biggs, R., and Macfarlane, R.G. : Human blood coagulation and its disorders. p. 74, Blackwell, Oxford, 1962.

23）松岡松三，佐竹清人，深澤落: Thyrosine 法による 血采フィブリノーゲソの定量法. 臨床梌查， 2，61， 1958.

24）佐竹清人，中田英策，盤若博司，分幡浩二，䄸貫実， 壬生倉裕, 関谷政雄, 小鳥直彦, 皆川彰, 牛山清司: 凝血因子の動態からみた訮・胆道疾患一をくに凝血因 子検索の診断的意義について一. 綜合臨床，12，1087， 1963.

25) Munro, H.N., Steele, M.H., and Forbes, W. : Effect of dietary protein level on deposition of cholesterol in the tissues of the cholesterol-fed rabbit. Br. J. Exp. Pathol., 46, 489, 1965.

26）後藤昌司：多变量デー夕の解析法. p. 241, 科学情報 社, 東京, 1973 .

27) Lombardi, V., Scandigli, G., and Guidi, G. : Ulteriore contributo allo studio della ipercoagulabilita ematica nel diabete presenile. G. Gerontol., 1, 957, 1959.

28）松永藤雄, 久保明良, 佐藤光, 松崎德满, 千葉陽一： 楛尿病患者の脈管障害に関する研究 (第 3 報). 糖尿病, 7, 180, 1964 .
29）富永雄幸，立井哲三，野入拓哉，宮尾定信，三村悟郎，

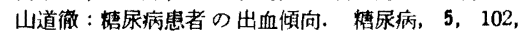
1962.

30）松永実, 尾上久吾, 油谷友三, 西村觟, 岩佐彰久, 野

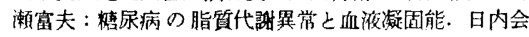
誌, 53, 370, 1964.

31) Alberini, B., Lasagna, G.C., and Tedeschi, G. : Il fattore VII nella malattia diabetica. Prog. Med., 17, 430, 1961.

32) Mayne, E.E., Bridges, J.M., and Weaver, J.A. : Platelet adhesiveness, plasma fiblinogen and factor VIII levels in diabetes mellitus. Diabetologia, 6, 436, 1970.

33) Angeli, G., Albertini, B., and Lasagna, G.C. : Il quadro emocoagulativo del diabete mellito. Riforma Med., 14, 10, 1960.

34）油谷友三，尾上久吾，猪井重幸，河野圭二，福田慧， 松永实，小楆邦䊒，西村侑，野濑管夫：模尿病患者の 血液㠜固能儿ついて. 榙尿病，6，75，1963.

35) Introzzi, P., and de Nicola, P.: Thrombophilia in diabetes. Thrombelastographic investigation. Diabetes, 6, 443, 1957.

36) Cantelli, T., Morsiani, M., and La Paglia, S. : Rilievi tromboelastografici nel diabete mellito. Prog. Med., 14, 466, 1958.

37) Dettori, A.G., Cucurachi, L., and Portioli, R.I. : Rapporti tra ipercoagulabilità e dislipidemia nei diabetici. G. Geront., 7, 941, 1959.

38) Alberini, B., Tedeschi, G., Lasagna, G.C., and Schiavi, L. : Ricerche tromboelastografiche nel diabete mellito. Rifoma Med., 75, 957, 1961.

39) Mann, G.V., Andrus, S.B., McNally, A., and Stare, F.J. : Experimental atherosclerosis in cebus monky. J. Exp. Med., 98, 195, 1953.

40) Greer, S.A.N., Hays, V.W., Speer, V.C., and McCall, J.T. : Effect of dietary fat, protein and cholesterol on atherosclerosis in swine. J. Nutr., 90, 183, 1966.

41) Barnes, R.H., Kwong, E., Pond, W., Lowry, R., and Loosli, J.K. : Dietary fat and protein and serum cholesterol. Young Swine. J. Nutr., 69, 269, 1959.

42) Moreland, A.F., Clarkson, T.B., and Lofland, H.B. : Atherosclerosis in "minature" swine. Arch. Path., 76, 203, 1963.

43) Keys, A., and Anderson, J.A. : Dietary protein and the serum cholesterol in man. Am. J. Clin. Nutr., 5, 29, 1957.

44) Olson, R.E., Vester, J.W., Gursey, D., Davis, N., and Longman, D. : The effect of low-protein diets upon serum cholesterol in man. Am. J. Clin. Nutr.. 6, 310, 1958.

45) Meeker, D.R., and Kesten, H.D. : Effect of high protein diets on experimental atherosclerosis of rabbits. Arch. Path., 31, 147, 1941.

46）吉岡正人：実倹的動脈硬化症におよほす食饵性脂質お よび蛋白質の影蠁. 日内会誌，60，821，1971.

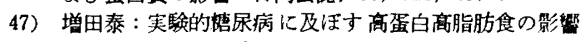
について. 長崎医誌, 39, 598, 1964. 
$-30-(330)$

48) Nishida, T., Yeno, A., and Kummerow, F.A. : Effect of dietary protein on the metabolism of sodium acetate-1-C 14 in chicks. J. Nutr. 11, 379. 1960.
49) Nishida, T., Yeno, A., and Kummerow, F.A. Metabolism of cholesterol-4-C in bile duct cannulated chicks and rats. Circ. Res., 8. 742, 1960. （受付：1977年 4 月 1 日) 